\title{
RESULT OF FURTHER LEGISLATIVE REGULATION OF ELECTRIC RAILWAYS
}

\author{
By John Blair Mac Afee, \\ Philadelphia, President Central Kentucky Traction Company.
}

What will be the result of further legislative regulation of electric railways? The interurban and intramural electric railway have become identified one with the other, are operated in close harmony, and in most states are treated as the same class of transportation enterprise. Legislative action, taken within the past few years, has had a tendency to restrict the investment of capital in new enterprises of this class. The man of money who embarks in a new electric railway enterprise must, under ordinary circumstances, be one of great courage. Under present conditions, due to adverse legislation in many states, he should be called a hero. The promotion of additional electric railways has been rendered extremely difficult because of the fact that the promoter must needs show the prospective investor a possible profit greater than the established income rate on "safe" securities. It matters not what tempting profit the promoter may offer, the prospective investor has before his mind stories of receiverships and business embarrassments attendant upon many electric railway enterprises. The capitalist, thoughtful of his own interests, therefore hesitates, and as a result the enterprise fails to mature.

The history of street and electric railways in this country proves, beyond a doubt, that the primary investor has received little if any interest upon his investment for periods of years after construction and the beginning of operation. It apparently requires three classes or types of men to put an electric railway into successful operation and keep it there. First, the promoter; second, the quasi-investor; third, the real investor.

The promoter, with flattering facts and figures, induces the quasi-investor to furnish the money with which the road is constructed and put in operation. For this service the quasi-investor gets the bonds of the road at less than par and with stock bonus, the percentage of which bonus is regulated in proportion to the discount

(695) 
on his bonds. The first effort of this individual is to unload his securities upon the investor, of course at a profit. He may have to wait until the road has demonstrated its ability to earn its fixed charges, taxes and operating expenses. In accordance with these returns he puts a price upon his bonds. If the road is a great success, the price is high and the bonds are sold with little or no stock bonus, the quasi-investor retaining the stock. Should, however, the returns be small, he may have to sell the bonds below par and throw in the greater portion of the stock that he received as bonus, in order to be relieved of the burden of carrying the securities. The real investor is the man who carries the bag, as a rule. Convinced of the possibilities of the line, perhaps due to a patriotic feeling, confident of the growth of his city and country, he is willing to buy the stock at a low price and wait for returns. As I have before stated, however, these waits are invariably long.

Street railways have been built rapidly in the last fifteen years, largely because of the profits made by the old horse-car lines, which profits came to them in bulk at the time of the transition from horse to electric power. In promoting a new line, the astute individual handling the "proposition" makes no reference to the fact that these old-established horse-car lines were on the best streets of the cityin the ordinary avenues of travel. The inventor, inexperienced in the operation of such utility companies, is not heedful of this fact. The new lines of travel have to be built and the goodwill established.

The mileage of electric railway has increased in this country from approximately 2,000 miles in 1894 to about 40,000 miles in 1907. Transportation, both intramural and interurban, has been made easy. Some people have made money. As a result, legislatures are invoked to restrict the franchises. Some states in which the franchise was unlimited or perpetual have passed acts limiting the life of the franchise to twenty, twenty-five and thirty years. In other states enactments have been made requiring the electric railway to light the streets of cities traversed by their tracks, free of cost to the municipality. Restrictive speed regulations have been adopted. In one growing, thriving community all cars are required to reduce speed to three and a half miles an hour in crossing streets. If this were strictly adhered to the time occupied in transit would be so long that an average walker could almost keep pace with the car. 
I think the average electric railway promoter does not complain particularly of the restriction of the life of the franchise. The investor, however, does. Money seeks permanent investment, and to say that a bond, for instance, is "well-held" is to imply that it is in the box of an estate, there to lie undisturbed for many years, except at coupon time. Trustees, guardians and other fiduciaries do not care, first, to have the trouble of reinvestment, and, second, are fearful of gradually reduced rates and interest. In shortening the life of the franchise the most potent thing that has been done is to compel the promoters or quasi-investors to sell the bonds at a less price than they would if the bond had a longer life. The life of the bond is usually limited within the range of the franchise. In this way the bonded debt is made greater than it should be, for the reason that the promoters or originators are determined, as far as they are concerned, to make as much money on the short term franchise as on the perpetual franchise. Increasing the bonded debt makes the burden of the railway greater and is in the main provocative of financial embarrassment.

Legislative restriction is therefore directly responsible for the curbing of enterprise. For instance, the number of new lines of electric railway projected in the past year was less than the number projected in the preceding year, and thus far this year, owing perhaps to general depressed financial conditions, the tendency to restrict investments of the sort has continued to increase. Restriction has frightened capital, confidence has been lost in the ability of the railway to earn its fixed charges, because of the unusual burdens, hence new capital cannot be secured. Failure to enlist new capital prevents extensions and building of new lines.

No other force has been so potent in building up the suburbs of cities, both great and small, as the transportation afforded by electric lines. Congested districts in large cities have to a great extent been turned over to business purposes, and the small, neat cottage in the suburbs has taken the place of the unsanitary tenement. Health conditions have improved, to say nothing of moral conditions.

If the restriction of enterprise favoring extensionh continues, it follows, as the night the day, that the growth of cities will be restricted and the prosperity of the country threatened. We do not mean to have it inferred that electric railways should have unlimited 
franchises, or that the operation of roads without proper legislative regulation should be allowed. But electric railway operators, the men whose time and money are given to this busincss, feel that such regulation should be the result of conference and study and that large capital interests invested in electric railway enterprises should not be threatened by populistic, socialistic or anarchistic movements, resulting in confiscatory enactment.

The operation of electric railways to-day is a scientific pursuit. Talented young men of the country are coming to the front in the development and operation of the enterprises. Their sole purpose is to increase efficiency and decrease operating cost. In decreasing operating cost, they are not aiming at the wage earner; they feel that he, be he honest, is worthy of his hire. Their thought and attention is directed to a higher grade of construction, thus reducing maintenance charges; to higher electric and machine efficiency, reducing coal and water cost. The great, new power houses of the day need comparatively few men as compared with the oldfashioned power houses, where coal was hand-stoked, engines were hand-oiled, switches were thrown by hand. In the modern plant machine stokers, lubricating devices of great ingenuity and motor switches have been adopted. Cars are being made larger, with more motive power added, are kept cleaner and in better state of repair. These young scientists who are devoting their lives to these enterprises will be checked in their ambitious efforts by further legislative regulation. A field of endeavor and usefulness will be curtailed in its area.

The electric railway has not only built up the cities, but it has made suburban life more attractive. All the facilities and the comforts of city life, the educational and amusement opportunities heretofore only possessed by the dweller within the brick walls are now at the beck and call of many a remote dweller on the farm. Whether or not more dwellers in the outlying country districts shall have these opportunities meted out to them will be largely dependent upon whether or not there be further legislative regulation.

The fixing of rates of fare by corporation commissions and other bodies is attended with great risk to the commonwealth. Invariably the men composing these commissions are men of high character and much ability in their chosen profession-usually the law. As a rule, however, they are absolutely devoid of experi- 
ence in transportation as a business. Yet they presume to tell the operator, not only of the steam roads, but in some states of electric railways, what fares and rates they should charge.

The electric railway manager of to-day does not ask, "How much profit will there be in this form of operation?" He asks, primarily, "Can we do this without a loss?" His first thought is the protection of the interests of his company, but with this thought is allied so closely as to be almost inseparable, "How can I improve this company in the good will of the public?" If he can be sure that certain changes of operating detail can be made without attendant direct loss to his company, he will invariably adopt the change, feeling sure that it will ultimately prove profitable. Fares are reduced and changed or modified, ticket systems adopted, always with the thought of ultimate profit to the company, but that thought is based upon the knowledge that without the public good will there can be no profit.

As an illustration of some attempts at legislative regulation, let us cite an act introduced into the assembly of one of the Southern states, requiring electric railways operating lines more than twenty miles long to maintain tanks of fresh drinking water and toilet rooms, in and upon all of their passenger cars. Due to laws already upon the statute books of this state for separation of races, the enactment of this measure would have meant the installation of four toilet rooms and two drinking fountains in each "trolley" car. As a result of strenuous opposition it failed of passage. Again an act was introduced into the legislature of another state providing that cuspidors should be placed between each cross seat in each interurban electric car. Upon the representative of the railway interests suggesting to the committee of the legislature having the bill in charge that it was considered a misdemeanor to expectorate in public in many of the states, one of the legislators arose and said he "wanted to take advantage of the opportunity to advise the gentlemen that seventy per cent of the best gentlemen in his state chewed tobacco." Imagine the condition of ladies' summer gowns with a cuspidor in each seat with seventy per cent. of the men chewing tobacco.

In conclusion, we believe that further legislative regulation, unless begotten of the wisdom that comes with knowledge of the business and as a result of conference with those who follow electric 
railway management as a profession, will have as its result the curbing and checking for at least a term of years of an industry, an enterprise, a developing force that has done as much if not more than any other one agency toward the advancement of the interests of all of the people of this great country. 